\title{
Primary anetoderma
}

INSERM

\section{Source}

INSERM. (1999). Orphanet: an online rare disease and orphan drug data base. Primary

anetoderma. ORPHA:228272

Primary anetoderma is a rare skin disease characterized by loss of elastin tissue resulting in localized areas of flaccid skin in the absence of a secondary cause. 